\title{
JEPSON v. THE CANADIAN SALT COMPANY LIMITED
}

For corporations incorporated or continued under the Canada Business Corporations Act, ${ }_{1}^{1}$ there are a number of methods whereby a majority can eliminate a troublesome minority shareholding. ${ }^{2}$ The most attractive method appears to be an amalgamation of the jointly controlled corporation with another, the voting shares of which are held only by the majority. The "target" minority shareholders may elect either to accept an offer for their shares from their current corporation or to receive a nonvoting redeemable preference share in the amalgamated corporation. ${ }^{3}$ If they accept the first, they are of course no longer shareholders in either body; if the second, the controllers can redeem their shares at leisure, usually at a price equivalent to the purchase offer. In either case, the minority's voting strength and active share in corporate growth are ended.

The attraction of the amalgamation option is particularly obvious when it is compared with other methods of accomplishing the same result. A simple offer to purchase the minority's shares may always be declined; a take over bid under s. 199 requires approval of $90 \%$ of independently held shares; 4 a reclassification of the minority's shares to make them redeemable would require a separate class vote of the affected group..$^{5}$ An amalgamation on the other hand requires a simple $2 / 3$ majority vote and truly forces out the minority, leaving them no option of retaining their current interest. Moreover, the new Canada Business Corporations Act makes approval of amalgamations simpler than before. ${ }^{6}$ Not only has the requisite majority been reduced, but the minority no longer has any right to apply to court to set aside the amalgamation agreement. ${ }^{7}$

The return for this lessening of shareholder rights and the only ray of sunshine for a minority shareholder on amalgamation is the option under 8. 184 of the Act to dissent. Unfortunately, also like sunshine, it too may be quickly dimmed. The dissent provisions are filled with procedural pitfalls into which the unadvised minority shareholder may tumble. Even if he succeeds in avoiding these, his remedy is merely to have his shares bought out at a "fair value." Difficulties in establishing fair value may convert his right into one of participation in expensive litigation against a well prepared opponent, competing for the uncertain prize of a

1. S.C. $1974-75$, c. 33 as am. S.C. $1978-79$, c. 11.

2. See Schwartz and Glover, "Going Private in Canada" (1978) 3 Can. Bus. L.J. 3 for a discussion of the various methods in some detail.

3. This particular form of amalgamation squeeze-out is, of course, only made possible by the C.B.C.A. permitting a corporation to purchase its own shares. See 8. 32 .

4. Supra n. 1. The requirement of independence of the majority is now statutory. Previously, however, this was implied by the courts in Esso Standard (Inter-Amer.) Inc. v. J.W. Enterprises Inc. [1963] S.C.R. 144.

5. Supra n. 1, 8. 170. The requirement of a class vote for some types of amalgamation schemes is still undecided. See Alexander, infra n. 23 or Canton Realty Co. Ltd. v. Maple Leaf Mills Ltd. (1978) 93 D.L.R. (3d) 106 (Ont. H.C.).

6. Supra n. 1, 8. 175 .

7. The previous Act provided for a $3 / 4$ majority approval and a right in a holder of at least $10 \%$ of the shares to apply to court for relief. Canada Corporations Act, R.S.C. 1970, c. C-32, s. 137.

8. S. 184 contains at least seven inter-dependent time limitations, requiring action by the shareholder or the corporation. See also generally Braun \& Lansky, "The Appraisal Remedy for Dissenting Shareholders in Canada: Is It Effective?" (1978) 8 Man. L.J. 683. 
court award higher than the original offer. ${ }^{9}$ While supposedly extending a new protection to the minority shareholder, this dissent right when combined with new amalgamation provisions makes him more vulnerable than ever before.

Recently, two cases, of which Jepson v. The Canadian Salt Company Limited ${ }^{10}$ is one, ${ }^{11}$ have suggested that the minority shareholder is not without support. What the legislature will not do it appears the courts will, interpreting a number of ambiguities in the legislation as "cracks and crevices" 12 through which "the common law will blossom . . . and try to ensure that justice is done."13

Jepson is an illustration of an amalgamation force-out of the type described above. Canadian Salt was controlled by Morton Industries of Canada Ltd. ("MIC") which owned approximately $80 \%$ of its issued shares. MIC was a wholly owned subsidiary of Morton-Norwich Products Inc. MIC made an offer for the minority shareholding in Canadian Salt, at $\$ 20$ per share, to be followed by an amalgamation between MIC and Salt whereby Morton-Norwich would receive one share of the amalgamated company for each of its shares in MIC; MIC would receive nothing for its shares of Salt; and the minority Salt shareholders (if any remained) would receive one $\$ 20$ redeemable preference share of the new entity. Clearly, the vote on the amalgamation was a foregone conclusion and no secret was made of management's intention to redeem the preference shares at the earliest date..$^{14}$

Mr. Jepson and his family wrote a number of letters objecting to the proposal, the last of which was written ten days before the meeting held to consider the amalgamation. Unfortunately, the Jepsons failed in several respects to comply strictly with the wording of $\mathbf{s} .184$ of the Act and, upon their application to establish the value of their shares for purposes of that section, the amalgamated Salt company raised as a preliminary point the Jepsons' right to bring the application.

The failures of compliance alleged were that no proper objection had been sent to the corporation prior to the meeting as required by subsection (5); that the notice sent after the meeting pursuant to subsection (7) was defective for failing to specify the number and class of the dissenting shares; that the Jepsons had failed to submit their share certificates to the corporation within the required 30 days after sending the subsection (7) notice; that the application was not brought in a proper form; and that the Jepsons were two days out of time in making their application under subsection (15). The very list of these allegations supports the view of the learned judge that the dissent provision is "a remarkably rigid procedure which, moreover, seems to be slanted in favour of the amalgamated corporation and against a dissenting shareholder." 15

Further, the suggested consequences of these failures were extremely harsh. After sending notice of dissent under subsection (7) the

9. See Manning, "An Essay for Frank W. Coker", (1962) 72 Yale L.J. 223 at 232 for a discussion of this aspect.

10. [1979] 4 W.W.R. 35 (Alta. S.C.T.D.).

11. The other is Neonex International Ltd. v. Kolasa [1978] 2 W.W.R. 593 (B.C.S.C.). See infra n. 25.

12. Id. at 601, quoted in Jepson, supra n. 10 at 42.

13. Id.

14. As the judge noted at Jepson 38 , there was a "barely veiled threat" that the shareholders would receive $\$ 20$, now or later.

15. Supra n. 10 at 42. 
shareholder ceases to have any rights in the corporation except the right to be paid the fair value of his shares under section $184 .^{16}$ However, subsection (9) provides that if the shareholder fails to submit his share certificates in the required time, he loses all rights to make application under the section. A similar implication may be drawn from failure to bring the application in the time allowed. Where then does this leave the dissenter? Counsel for the amalgamated corporation apparently argued that the shareholder who sent a valid subsection (7) notice, but failed to comply with the other subsections, was left without his shareholder's rights and without any right or any mechanism to have the value of his shares determined. This interpretation could arguably deprive him of his investment completely.

Laycraft $\mathrm{J}$. held that none of the alleged deficiencies were fatal. In doing so, he raised and established a number of important points governing the interpretation of s. 184 and, even more significantly, affirmed the intention of the courts to supervise closely dissent proceedings arising from statutory amalgamations. As to the first two objections, he held that the original dissent notice did not need to be in any particular form and that a passing reference in the subsection (7) notice to an earlier letter specifying the dissenters' shareholdings was sufficient compliance. Also, no particular form of application was required for court proceedings under subsection (15). In answer to the more serious objection that the share certificates were not submitted, he found that the corporation had waived its right to insist on such submission by the terms of its letter informing shareholders of the results of amalgamation. That letter attached the preferred share certificate of amalgamated Salt and noted that the old certificates did not need to be returned, but were "worthless paper". The letter did not refer to any dissenting shareholders. Finally, considering the difficulty in complying with the time limitation for bringing the action, the court held that an absurdity would result unless the time were held to run from the date on which the shareholder became aware that his corporation had not itself applied under the section rather than from the final day on which the corporation could have applied. This latter interpretation may have been rendered unnecessary by amendments to the section permitting the court to extend this time limit. ${ }^{17}$ However, the extensions are discretionary and a shareholder might understandably prefer to argue that he is strictly within the time limit.

The Jepson decision should be welcomed as a sign that, despite the detailed procedures in the Act, the courts are prepared to assume a much needed role in seeing the section fairly applied. Of course, under the Canada Business Corporations Act, the shareholder has a range of additional remedies that may ameliorate his situation. As has been observed, the dissent remedy provides only a minimum of fairness to the shareholder while permitting the corporation maximum freedom to arrange its affairs in accordance with its controllers' interests. ${ }^{18}$ Since the dissent remedy is not exclusive, ${ }^{19}$ the shareholder may also, for example,

16. Subsection (11). These consequences, of course, would only follow if the subsection (7) notice were good. If it were not, presumably only the 8 . 184 right would be lost. The Jepsons would retain their shareholdings and be left with the redeemable preference share.

17. S.C. $1978-79$, c. 9 , s. $60(4)$.

18. Magnet, "Shareholders' Appraisal Rights in Canada" (1979), 11 Ottawa L.R. 98 at 122.

19. Supra n. 1, 8. 184(3). 
apply to the court for relief under the oppression sections. ${ }^{20}$ These sections give the court sweeping powers which would allow it to intervene in the amalgamation agreement itself and even set aside the transaction ${ }^{21}$ were it shown that the approval of the agreement was an act unfairly disregarding the interests of the complainant. Arguably, an amalgamation made with no business purpose other than removing a minority interest could always be considered unfair treatment of a shareholder within the meaning of the Act.22

Yet the oppression remedy is directed only toward the extreme case. Moreover, it is largely untested in its extent. ${ }^{23}$ Jepson $^{24}$ will be more comfort to the shareholder who is prepared to accept the amalgamation, but wants only the rights which Parliament has ostensibly provided. The barriers to these rights have, as noted, been twofold: the procedural complexities of the section, and the difficulties of proving the fair value of the shares. Neonex International Ltd. v. Kolasa, 25 a B.C. Supreme Court decision cited with approval in Jepson, held that in a similar situation the burden of proving the fair value of the shares rested upon the corporation. Since the shareholder is given by the Act the right to the fair value of the shares ${ }^{26}$ and since the corporation is required to offer a price believed by the directors to be the fair value, ${ }^{27}$ this interpretation appears correct. The corporation should logically bear the burden of proving that the value it has alleged to be fair is 80 in fact. It is also reasonable that since the corporation has the only access to many factors affecting their shares, it should be required to rely on this information. The shareholder is otherwise at a tremendous disadvantage under the section.

The Neonex case established precedent for giving to s. 184 a remedial interpretation. Parliament had deprived shareholders of certain rights on amalgamation and given them in turn the right to dissent. Therefore, the courts would ensure that the new right was fairly applied. In considering the requirement that share certificates be submitted to the corporation as a right of the corporation that could be waived; in interpreting a general letter to shareholders to be effective waiver; in relating the time limitation to the date of knowledge of the shareholder, rather than merely to the expiration of the fifty days allowed the corporation to apply to court as a literal reading of the section would suggest; and in permitting substantial rather than strict compliance with notice provisions, Laycraft J. followed and extended this approach to the procedural problems of the section.

20. Id., 8. 231 , s8. $234-235$.

21. Id., subsection 234(3) gives the court power to vary or set aside a transaction or contract to which a corporation is a party.

22. This could import into Canadian law a "business purpose test" bearing some similarity to that in American jurisdictions. See Singer v. Magnovox Co. 380 A. (2d) 969 (Del. S.C. 1977). However, the basis would be statutory rather than a duty of the majority shareholder to the minority.

23. In Alexander et al. v. Westeel-Rosco Ltd. et al. (1978) 93 D.L.R. (3d) 116, the Ontario High Court granted an interim injunction restraining a corporation from holding a meeting to consider a proposed amalgamation under the C.B.C.A. Inter alia, the court expressed its opinion that the amalgamation designed to force out the minority was actionable under 8.234 of the C.B.C.A. However, the court noted that the issue was better left to a trial judge hearing the evidence.

24. Supra n. 10. The objection would be not to the vote of the majority, but to the resolution of the corporation approving the amalgamation agreement.

25. Supra n. 11.

26. Supra n. 1, 8. 184(3). At the time of the Neonex decision, this required the exclusion of any effects on value of the contemplated amalgamation. This was amended simply to require the "fair value". Supre n. 17, 8. 60(2).

27. Supra n. 1, s. 184(12). 
A few questions still remain. Both Neonex and Jepson deal with the dissent procedures on amalgamations, and in both the courts relied heavily on the change in shareholders' rights on amalgamations to support their conclusions. The element of expropriation in the squeeze-out is stressed. Yet s. 184 applies to a number of other cases as well: to shareholders of a corporation which resolves to amend its articles to alter transfer restrictions or other special rights of a share class; to change restrictions on business contained in the articles; to continue under another jurisdiction; or to sell the corporation's property. ${ }^{28}$ Will Neonex and Jepson apply as well to s. 184 proceedings in these situations? In most, the special resolution needed to accomplish the changes does not require a smaller majority than did a special resolution under the previous Act. ${ }^{29}$ In many, the act will result in the transformation of the shareholder's interest to a very different one, perhaps less advantageous to him. Yet all these procedures, including amalgamations, may be used to produce results that do not entail virtual expropriation of a shareholder's interests. If an element of expropriation is necessary to allow a liberal interpretation of 8 . 184, the courts will be required to examine the effects of each transaction before deciding on their approach to the section. This seems unjustifiable, particularly in view of the fact that strict application of the section may itself expropriate the shareholder's rights for a minor failure of compliance.

This possible consequence of failing to meet all the requirements of $\mathbf{s}$. 184 is another unresolved issue. Laycraft $\mathrm{J}$. agreed that loss of the shareholders' investment could be the result. ${ }^{30}$ While the section does not specify this, it is difficult to come to any other conclusion. As the judge also observed, there appear to be no deleterious effects on the corporation should it not follow the s. 184 procedures. ${ }^{31}$ In fact, the corporation can only benefit. The idea that the corporation need only remain uninvolved and, if fortunate, will find enough procedural errors on the part of its dissenting shareholders to obliterate both the shareholding and the need to compensate the shareholder is totally repugnant to the policy of the section. ${ }^{32}$

If the degree of freedom for corporate change conferred by the C.B.C.A. is needed in our economic system, then so too is the dissent procedure. As Magnet observes in his article "Shareholders' Appraisal Rights in Canada", the procedure "is a means of keeping the shareholders' heads above water when the seas get rough." 33 Yet the difficulties with the

28. Supra n. 1, 8. 184(1).

29. Of course, most of these changes were not matters considered by the previous Act, but a special resolution for most changes to the corporation required only a $2 / 3$ majority vote. Amalgamations and compromises were exceptions requiring a 3/4 majority. See supra n. 7, 8 . 134 and 8. 137.

30. Supra n. 10 at 42 . Since His Lordship decided the case on the grounds that the application was properly brought, this point did not have to be resolved. However, he does note "failure by the shareholder to observe some provision of the section can result in the draconian penalty of complete loss of his investment in the corporation."

31. Id.

32. As Magnet notes, the section is not provided to assist the corporation in acquiring minority interests. Supra n. 18 at 108. However, even though, in Magnet's words, "the suggestion made in the Kolasa case that the company acquired rights under section 184 is unsupportable and ought not to be followed" the judge in Kolasa may have been making less a suggestion of policy behind the section than a statement of the obvious uses to which the section can be put. By an excessive stressing of procedural niceties, Parliament has given the corporation a useful weapon in a force out. This is illustrated by the facts of the cases decided under the question.

33. Id. at 162 . 
section, as revealed in the case law, are enormous. Only a remedial approach by the courts based on a determination to ensure that the section is an instrument of justice and fairness can, it would seem, make this purported lifejacket actually float.

Yet despite the laudable approach of the court in Jepson the solution obviously lies in legislative amendment. It should not be necessary to rely upon a chance reference to earlier correspondence to fulfill a statutory requirement which, as the court pointed out, merely provides information readily available to the corporation..$^{34}$ Nor should it be necessary to interpret the legislation as broadly as did the court to avoid absurd or harsh results. The procedure could be simplified and the results of failing to comply with it clarified. Jepson illuminates many of the weaknesses in the section and could serve as a blueprint for amendment.

Mary Anne Waldron*

34. Subsection (4) provides that the shareholder may not dissent for a portion of the shares of a class, unless they are held by him for more than one beneficial owner. Presumably, it would only be in this latter case that the corporation would need to know from the shareholder the shares with respect to which he dissents. The information might also be required if the section permits dissent on one class, but not on another beneficially owned by the same person. This is ambiguous. Presumably, however, these cases would be sufficiently rare that a presumption could be made that the dissent covered all the shares registered in the name of the dissenter. This would avoid at least one more procedural tangle.

- Assistant Professor, Faculty of Law, University of Victoria. 